\title{
Opinto-ohjelmien hallinnan ja kehittämistyön haasteita ja mahdollisuuksia
}

\author{
Tarkastelemme opinto-ohjelmien hallintaa ja kehittämistä yliopistoissa \\ tehtävänä arkisena työnä. Haluamme kiinnittää huomiota siihen, millaista \\ tämä työ on käytännössä ja kuka tai ketkä sitä oikein tekevät. Haluamme \\ herättää keskustelua, miten voisimme ymmärtää kollegojemme vastaavaa \\ työtä tässä monien mahdollisuuksien ja pakkojen maailmassa.
}

OPINTO-OHJELMISTA eri tavoin vastuussa olevat ihmiset työskentelevät usein monenlaisilla nimikkeillä, hyvin erilaisista asemista ja lähtökohdista, etenkin suhteessa valtaan ja käytettävissä oleviin resursseihin. Yksityiskohtaisempi ymmärrys näiden ohjelmajohtajien, yliopistolehtoreiden, tutkijaopettajien, assistenttien ja/tai korkeakoulusihteereiden työtehtävistä opinto-ohjelmien parissa loisi mielestämme paremmat edellytykset ohjelmien pitkäjänteiselle kehittämiselle.

Oma näkökulmamme opinto-ohjelmien hallintaan ja kehittämiseen on tarkastella sitä käytännöllisenä toimintana. Kyse on monista erilaisista työtehtävistä, joita opinto-ohjelmista vastuussa olevat toimijat kohtaavat ja hoitavat, usein oman tutkimus- ja opetustyönsä ohella. Tuomme omakohtaisten esimerkkien avulla näkyville näitä ohjelmallisten kokonaisuuksien hallintaan ja kehittämiseen liitty- viä työtehtäviä. Esittelemme myös lähestymistavan, jonka avulla voimme keskustella ja etsiä vastauksia ohjelmatyöskentelyn keinoihin, tavoitteisiin, moraalisiin motiiveihin ja ammatillisiin identiteetteihin liittyviin kysymyksiin. Haemme näin selkeyttä omaan työhömme. Samalla haluamme herättää keskustelua ohjelmatyöskentelyn kollektiivisista haasteista ja mahdollisuuksista: miten opinto-ohjelmissa työskentelevät toimijat voisivat ymmärtää kollegojensa toimintaa tässä monien mahdollisuuksien ja pakkojen maailmassa?

\section{OHJELMALLISEN AJATTELUN KASVU KORKEAKOULUISSA}

Kirjoituksemme perustuu omiin työkokemuksiimme Aalto-yliopiston kauppakorkeakoulussa, missä olemme työskennelleet aineyksikkömme assistenttina ja ohjelmajohtajana usean vuoden ajan. Olemme 
olleet todistamassa, miten puhe "ohjelmallisuudesta" on lisääntynyt, kun esimerkiksi Bologna-prosessin ${ }^{1}$ myötä kandi- ja maisteriohjelmat erotettiin erillisiksi ohjelmikseen. Aalto-yliopistofuusion myötä myös ohjelmallinen toimintaympäristö on muuttunut laajemmaksi ja monimutkaisemmaksi kokonaisuudeksi. Uusia poikkitieteellisiä opinto-ohjelmia ja kursseja suunnitellaan, käynnistellään ja markkinoidaan monissa uuden yliopiston yksiköissä. Opiskeluoikeuksiin liittyviä sääntöjä muokataan ja sovitellaan jo olemassa oleviin ohjelmiin ympäri yliopistoa. Samaan aikaan vanhoja, opinto-ohjelmiksi kutsuttavia erilaisia opintokokonaisuuksia uudistetaan ja myös arvioidaan sekä kansallisten että kansainvälisten arvioijien toimesta ${ }^{2}$.

Koemme, että tässä toimintaympäristön murroksessa olisi entistä tärkeämpää nähdä ja tunnistaa, mitä tämä ”ohjelmallisuus” pitää sisällään: mitä on se työ, jota joidenkin on tehtävä, jotta niin opiskelijat kuin tutkijaopettajatkin tunnistaisivat toimivansa jonkun tietyn ohjelman puitteissa? Hyvin tehtynä opinto-ohjelmien suunnittelu, hallinnoiminen ja kehittäminen ovat vaativaa työtä, jota kukaan yksittäinen toimija ei pysty yksin hallitsemaan. Siihen liittyy paljon muutakin kuin vain joka keväinen opintooppaan tietojen kokoaminen ja toimittaminen opaskirjaseksi. Se on työtä, joka tarvitsee omat tekijänsä nimettyine vastuineen ja resursseineen. Vasta hahmottuvassa olevassa toimintaympäristössä tarvitaan myös toimijoita, jotka tuntevat jo olemassa olevat opinto-ohjelmat ja niiden toimintaedellytykset. Seuraavaksi kerromme, mitä tarkoitamme ohjelmien parissa työskentelyllä.

\section{OHJELMALLISUUS TYÖTEHTÄVINÄ}

Opinto-ohjelmatyöskentely voidaan nähdä monien toisiinsa liittyvien työtehtävien verkostona, johon kuuluu mm. erilaisia opiskelijoiden valintaa, ohjelmien suunnittelua, toteuttamista ja arviointia koskevia tehtäviä. Osa näistä on harvakseltaan toistuvia työtehtäviä, joihin liittyy suhteellisen vakiintuneita toimintatapoja. Osa työtehtävistä on luonteeltaan jatkuvia ja osa puolestaan yllättäviä, välitöntä huomiota vaativia tehtäviä, joiden hoitaminen sekoittaa opinto-ohjelmien parissa työskentelevien arkipäiviä toistuvasti.
Työskennellessämme aineyksikkömme opintoohjelmien parissa olemme usein todenneet, että mikäli ohjelmallisuuden halutaan toteutuvan, pitäisi siihen liittyvät työtehtävät pystyä tunnistamaan ja myös hoitamaan edes kohtuullisesti. Kokemuksemme mukaan ohjelmajohtajat ja assistentti joutuvat jatkuvasti pohtimaan useita opinto-ohjelmiin liittyviä kysymyksiä. Perusteltu mielipide näihin kysymyksiin edellyttää paitsi oman koulukohtaisen järjestelmän tuntemusta, myös kiinnostusta korkeakoulutuksen kenttään ja alan tutkimuksen kautta muodostuvaa näkemystä’ ohjelmallisuuden' eri muodoista ja mahdollisuuksista.

Yliopistokoulutusta koskevassa tutkimuksessa lähdetään usein liikkeelle yksittäisten opettajien ja opiskelijoiden tieto- ja oppimiskäsityksistä sekä opettamis- ja oppimismenetelmistä (Postareff et al. 2008; Haggis 2009). Lähtökohta on myös tyypillinen erilaisissa yliopistopedagogisissa koulutuksissa, joihin olemme itsekin viime vuosina osallistuneet. Näissä koulutuksissa pyritään tukemaan yksittäisten opettajien kehittymistä opettamisen taidoissa ja opiskelijoiden oppimisen ohjaamisessa. Tällainen tapa käsitellä koulutuksen ja oppimisen kysymyksiä irrallaan siitä työn tekemisen kontekstista ja niistä edellytyksistä, joissa näitä asioita ratkotaan, on kuitenkin ongelmallinen. Jos opetussuunnitelmatyön kehittäminen ja sen edellytykset jäävät liian vähälle huomiolle (vrt. Barnett \& Coate 2005), luodaan koulutuksessa helposti pedagogisia ideaalimalleja, joiden toteuttamisen edellytykset saattavat puuttua kokonaan. Keskittyminen opettamisen tekniikkaan voi myös eriyttää kahta keskeisintä akateemisen työn osa-aluetta - opetusta ja tutkimusta - vain kauemmaksi toisistaan.

Oma lähtökohtamme onkin tutkia opinto-ohjelmien hallintaa ja kehittämistä käytännöllisenä toimintana, jota tehdään osana laajempaa akateemisen työn kokonaisuutta paikallisissa oppiaine- ja tiedekulttuureissa (ks. esim. Mäntylä 2007). Esittelemme seuraavaksi tehtäviä, jotka ovat olleet meille keskeisiä ohjelmallisuutta ja omaa arkeamme määrittäviä työtehtäviä. Osa näistä määrittää työtämme voimakkaasti ja osa vain hipaisee työpäiviämme. Osa tulee näkyville sen takia, ettei kyseinen työtehtävä tunnu 
olevan oikein kenenkään hoitama. Annamme omakohtaisen esimerkin kustakin tehtävästä ja kerromme, miksi pidämme näitä tehtäviä oleellisina ja miten niiden hoitaminen voisi tukea koulutusohjelmien hallintaa ja kehittämistä.

\section{Opiskelijoiden valinta ja opiskelijarekistereiden ylläpito}

"Maanantai 30.8. - Olen uusien, koulun ulkopuolelta valittujen maisteriopiskelijoiden tervetuliaistilaisuudessa puhumassa opiskelusta johtamisen ohjelmassa. Opiskelijat esittelevät itsensä ja innostun heidän taustoistaan: miten rikastavaa onkaan saada kauppatieteilijöiden sekaan muntama kasvatustieteilijä tai valtiotieteilijä! Opiskelijat vaikuttavat innostuneilta ohjelmastamme, eikä ihme, onhan nämä 15 opiskelijaa valittu 243 hakijan joukosta."

Maisteri- ja kandiohjelmien eriyttämisen ja erillisten Aalto-tasoisten opinto-ohjelmien ${ }^{3}$ myötä maisteriopintoihin hakeudutaan nykyään erikseen. Näin myös ohjelmilla on enemmän mahdollisuuksia vaikuttaa siihen, keitä ohjelmiin valitaan ja miten. Ei kuitenkaan ole itsestään selvää, ketkä olisivat sopivimpia hakijoita ohjelmaan. Ohjelmien kannalta on merkityksellistä, että valintakriteerit ovat kohdallaan, valinnat tehdään huolellisesti ja että ohjelmasta vastuussa olevat henkilöt olisivat hyvin perillä siitä, millaiset opiskelijat ohjelmissamme opiskelevat.

\section{Opinto-ohjelman tavoitteista ja työskentelymuodoista sopiminen}

"Lauantai 12.3. - Saan varadekaaniltamme sähköpostin, jossa hän tiivistää näkemyksensä kandiohjelmien uudistusta valmistelevan työryhmän keskustelusta mm. seuraavasti: Uutta ohjelmaa hahmoteltaessa kysymys on pitkälti siitä, kuinka paljon opiskelijoille määrätään pakollisia yleisopintoja (... ), miten nämä rytmitetään sekä missä määrin ohjelmat tarjoavat valinnaisuutta ja liikkuvuutta. (... ) Määritetäänkö erikoistumisalueet kaikkine kursseineen etukäteen hyvinkin tarkasti (esim. laitosjaon mukaisesti) vai jätetäänkö erikoistumisalueet opiskelijan itsensä vapaasti muodostettaviksi (eli periaatteessa erikoistumisalueita tai -polkuja voisi olla niin paljon kuin meillä on kandiopiskelijoita)." Toimiva opinto-ohjelma ei voi olla yhden 'vastuuihmisen' päänsisäinen näkemys, eikä edes pienen valistuneen joukon opinto-oppaaseen pusertama kuvaus. Oman yksikkömme kandi- ja maisteriohjelmien parissa työskentelee noin 30--40 tutkijaopettajan joukko, yhdessä yliopistomme keskushallinnon toimijoiden ja yli 200 tutkinto-opiskelijan kanssa. Yksittäisten opettajien tekemät kurssikohtaiset ratkaisut voivat olla hyvin perusteltuja "sen oman kurssin” kannalta. Toisistaan erillään tehtyinä ne kuitenkin lisäävät ohjelmakokonaisuuden monimutkaisuutta ja vaikeaselkoisuutta sekä opiskelijoiden että toisten opettajien kannalta katsottuna. Sama pätee myös opintohallinnollisiin ratkaisuihin: yksittäinen uudistus esimerkiksi opiskelijavalinnan tai tutkintorakenteen osalta voi olla hallinnon näkökulmasta tarpeellinen, mutta ohjelmassa työskentelevien opettajien työn kannalta ristiriitainen. Lisäksi yhden kurssin tai yhden ohjelmakokonaisuuteen liittyvän työtehtävän parissa tehdyt ratkaisut vaikuttavat usein vasta muutaman vuoden viiveellä koko opinto-ohjelman toimivuuteen.

\section{Opettajien kanssa neuvottelu, opetustyöstä sopiminen ja kollegiaalinen vertaistuki}

"Perjantai 21.5. - Sain sähköpostin, jossa kerrottiin, että elokuusta lähtien koko tutkimus- ja opetushenkilöstö on kokonaistyöajan piirissä, aiemmasta poiketen myös tutkijakoulutettavat ja projektityöntekijät. Kokonaistyöaikaan siirtyminen tarkoittaa opetuksen osalta sitä, että kaikki sekä tutkivat että opettavat ja opetustuntimäärät on kirjattava tarkastettaviin työsuunnitelmiin."

Ohjelmallisuuden kannalta on oleellista tietää, ketkä ovat toteuttamassa yhteistä opinto-ohjelmaa - ja millä ehdoilla. Mikäli lähtökohdaksi hyväksytään se, että kaikki työsuhteessa olevat henkilöt opettavat riippumatta siitä, mitä he osaavat, on aika haastavaa lähteä kehittämään laadukasta opinto-ohjelmaa. Jos taas voimme kutsua opettajia opetustehtäviin sen mukaan, mitä opinto-ohjelman sisällölliset ja pedagogiset tavoitteet edellyttävät, olemme askeleen lä- 
hempänä selkeästi toimivaa ohjelmallisuutta.

Opettajien ammattitaitoa ja vertaistukea voi myös vahvistaa siten, että opetustyötä tehdään opinto-ohjelman kursseilla pareittain tai pienissä opettajaryhmissä, kollegiaalisesti neuvotellen ja yhteistyöstä sopien. Oma monivuotinen kokemuksemme on se, että hallitusti toteutettuna tämä lisää tutkijaopettajien mahdollisuuksia jakaa vastuuta ja uudistaa omia opetusmenetelmiään. Erilainen osaaminen ja kokemus voivat näin rikastaa toisiaan. Yhteisvastuullinen opettaminen ja opetuskokoonpanojen harkittu muuntelu ohjelman eri kursseilla voivat lisätä myös kurssien välistä koordinaatiota ja koko ohjelman toimivuutta merkittävästikin. Ohjelmallisuuden pitkäjänteinen kehittäminen on puolestaan vaikeaa, jos opinto-ohjelmasta vastaavat toimijat eivät voi vaikuttaa siihen, ketkä ohjelmassa opettavat.

\section{Opinto-oppaiden kokoaminen, toimittaminen ja opintojen ajoitus}

"Torstai 25.2. - Helmi-maaliskuu on kiireistä aikaa opinto-oppaaseen tulevien tietojen keräämisen ja toimittamisen suhteen. Opintokokonaisuuksia johtamisen kandi- ja maisteriohjelmassa on yhteensä 45, joista jokaisen kohdalta täytän opintotietojärjestelmään 10--15 tietokenttää, usein sekä englanniksi että suomeksi. Tätä tehdessä vastailen tutkijaopettajien kysymyksiin: miten lasketaan työmäärä toteutustavoittain? Voinko vielä vaihtaa kurssikirjan kirjallisuusvaatimuksiin? Mikä on poikkeava tai normaali ilmoittautumiskäytäntö? Tässä vaiheessa on vain saatava tiedot järjestelmään, muuta ei ehdi tekemään."

Opinto-ohjelman kursseista vastaavat opettajat ratkovat edellä kuvattuja opetustyön yksityiskohtia opinto-oppaan kokoamisen yhteydessä. Tällöin olisi myös mahdollisuus hakea yhtenäisiä ratkaisuja ja toimintatapoja moniin ohjelma- ja kurssikohtaisiin kysymyksiin. Mikäli opettajien keskinäistä opetustyötä koskevaa keskustelua ja yhteistä sopimista ei ole organisoitu omaksi työskentelyvaiheeksi tai osaksi olemassa olevia opinto-ohjelman suunniteluun kuuluvia työskentelytapoja, jää opinto-ohjelma helposti hajanaiseksi kurssi- ja informaatiokokoelmaksi. Täl- löin jokainen opettaja vain toimittaa opinto-opasta varten täytettävät informaatiokentät oman kurssinsa näkökulmasta. Oppaan toimitustyöstä vastaava henkilö puolestaan kokoaa tämän informaation tekstikokonaisuudeksi, jota sitten kutsutaan opintoohjelmaksi. Monet kysymykset siitä, miten eri kursseilla opiskeltavat sisällöt ja miten niillä toteutettavat työskentelytavat mahdollisesti liittyvät toisiinsa jäävät näin yksittäisten opiskelijoiden ja yksinäisten opettajien ratkaistaviksi.

Opinto-ohjelmiin valitut opiskelijat joutuvat myös sopeutumaan tietynlaiseen laskennalliseen opintojen mitoitukseen (esimerkiksi 3-vuotiseen kandi- ja 2-vuotiseen maisteriohjelmaan). Todellisuudessa moni opiskelija opiskelee ohjelman kursseja oman työn ja/tai perhe-elämänsä rinnalla. Ohjelmia voisi suunnitella myös siten, että ne palvelisivat joustavammin erilaisten opiskelijoiden erilaisia tarpeita. Osa ohjelmista voisi olla tiukkoja, tiettyyn suorittamisjärjestykseen ja aikatauluun perustuvia ratkaisuja, osa joustavampaan ja osa-aikaisempaan opiskeluun tarkoitettuja opintokokonaisuuksia. Se missä, milloin ja miten opiskelu tapahtuu, voitaisiin ratkaista myös luovemmilla tavoilla, kuin mihin perinteinen koulumainen luokkahuoneopetus antaa myöten. Tällöin myös kurssien vastuuopettajien olisi hyvä olla tietoisia siitä, minkälaisen ohjelman osana he kurssiaan toteuttavat.

\section{Yhteydenpito muihin opintoja tarjoaviin tahoihin ja keskushallintoon}

"Maaliskuun puolivälissä - kun opinto-opastekstit on jo toimitettu Akateemisten Asioiden Komitean vahvistettavaksi, paljastuu, että oppiaine, jonka kanssa olemme tehneet yhteistyötä tutkimusmenetelmiä koskevassa opetuksessa, onkin muuttanut ratkaisevasti omaa tarjontaansa. Myös meidän opintojen suunnittelu menee näin viime metreillä uuteen harkintaan."

Oma aineyksikkö tuttuine kollegoineen ei aina ole se porukka, jonka kanssa neuvotteluja opinto-ohjelmasta käydään. Mitä enemmän opinto-ohjelmia rakennetaan yhdistelemällä opintojaksoja tai yksittäisiä kursseja eri aineiden tarjonnasta, sitä monimutkai- 
semmaksi yhteydenpito ohjelmassa opettaviin tahoihin väistämättä muuttuu. Pikaisia neuvotteluja käydään ja kertaluonteisia sopimuksia tehdään etenkin keväällä opinto-oppaan kokoamisen yhteydessä. Osa sopimuksista uusitaan seuraavana vuonna, osa puretaan, ja osa unohtuu (opinto-oppaaseen) esimerkiksi kiireen ja lukuisten määräaikaisten toimijoiden vaihtuvuudesta aiheutuvien sekaannusten takia.

\section{Opiskelijoiden ohjaus}

"Maanantai 11.10. - Olen kandiseminaarissa puhumassa opiskelusta johtamisen maisteri-ohjelmassa. Kandiseminaareissa vieraileminen on yksi tapa saavuttaa maisterivaiheeseen jatkavat opiskelijat isompana ryhmänä edes jotenkin. Kaikki näistäkään opiskelijoista ei jatka johtamisen maisteriohjelmassa, sillä johtamisen kandiohjelma antaa valmiudet useisiin eri maisteriohjelmiin. Olen kuitenkin puhumassa ja keskustelemassa siitä, miten opiskelijat voisivat saada otteen maisteriopinnoista ja millaisia erilaisia mahdollisuuksia heillä on vahvistaa omaa toimijuuttaan ohjelmassamme."

Opiskelijoiden ohjauksessa ei tarvitsisi olla kyse vain pakollisesta Hopsin laatimisesta tai yksilöllisestä opintoneuvonnasta. Kyse voisi olla myös siitä, miten vahvistaa tietyn aineen opiskelijoiden käsitystä siitä, että he ovat juuri tietyn ohjelman opiskelijoita ja että he voivat tukea opinnoissa myös toisiaan. Silloin puhuttaisiin ohjelmallisesta kokonaisuudesta, tietynlaisista yli yksittäisten kurssien ulottuvista oppimistavoitteista, mahdollisista suosituksista eri kurssien suoritusjärjestyksissä ja ohjelmassa etenemisessä (ks. Räsänen \& Korpiaho 2007). Opiskelu kun ei ole pelkkää yksilösuorittamista, vaan yhteisöllistä siinä mielessä, että se tapahtuu tiedeyhteisössä, suhteessa muihin opiskelijoihin ja opinto-ohjelmasta vastuussa oleviin toimijoihin. Opiskelijoiden oman opiskeluorientaation löytämistä voitaisiin näin tukea ja vahvistaa läpi ohjelman. Tätä edesauttaisi se, että ohjelman tarjoamat yleiset ammatilliset, akateemiset, sosiaaliset ja henkilökohtaiset kehittymismahdollisuudet tuotaisiin näkyville ja että niiden parissa voitaisiin työskennellä myös yhteisesti.

\section{Yhteydenpito opiskelijajärjestöihin ja kerhoihin}

"Torstai 24.2. - Koko laitoksen henkilökunta saa kutsun ainejärjestömme syntymäpäiväjuhliin, ensi maanantai-iltana 'Yläkertsille'. Tapahtuma on opiskelijoille suunnattu, mutta laitoksen henkilökunnastakin toivotaan edustajia tilaisuuteen. Ainejärjestön hallitus esittäytyy ja muutoin ohjelmassa on tarjoilua, vapaata seurustelua sekä leikkimielisiä seurapelejä. Tervetuloa."

Opiskelijajärjestöt ja valiokunnat - esimerkiksi johtamisen opiskelijoiden oma ainekerho - pyrkivät pitämään yhteyttä laitoksen henkilökuntaan. Ainekerhon osalta kyse on usein ura- ja alumni-illoista, erilaisista yritysten kanssa järjestettävistä tapahtumista sekä osana opinto-ohjelmaamme järjestettävistä erityishankkeista. Näihin opiskelijat toivovat henkilökunnan aktiivista osallistumista. Opiskelijayhteistyö voisi olla paljon muutakin: heidän kanssa voisi järjestelmällisemmin keskustella ohjelmakokonaisuuksista ja ottaa heitä useammin mukaan koulutusohjelman kehittämiseen. Nämä ovat kuitenkin juuri niitä työtehtäviä, joiden suunnitteluun ja toteuttamiseen juuri kenelläkään ei tunnu olevan riittävästi aikaa.

\section{Ohjelmien esite- ja \\ markkinointimateriaalien valmistelu}

"Torstai 8.4. - Ohjelmamessuja varten suunnittelemamme uusi ohjelmaesite on vihdoin valmis! Tunnen itseni melkein oikeaksi toimittajaksi, kun pidän käsissäni kymmensivuista esitettä, jossa on ohjelmarakenteiden lisäksi valmistuneiden haastatteluja ja opiskelijoiden puheenvuoroja. Tutkijan työ on joskus yllättävän monipuolista."

Kun opinto-ohjelmat muistuttavat enemmän "ohjelmia” omine erillishakuineen ja valintakriteereineen, tulee myös ohjelmiin liittyvä markkinointi- ja esittelytyö eri tavoin tärkeäksi. Oman koulun ohjelmamessujen rinnalle on noussut Aalto-opiskelijoille suunnattua markkinointia, Mikkelin kandiohjelmassa opiskeleville suunnattuja messupäiviä, abi-markkinointia, jne. Omien ohjelmien markkinointi, esite- ja mainosmateriaalien valmistelu halutaan usein tehdä oman ohjelman lähtökohdista ja sisällöistä käsin, 
vaikkakin viestintäosasto tarjoaa tässä apuaan. Ohjelmat myös kilpailevat opiskelijoista, jotka tekevät omia valintojaan osin hyvien esitteiden ja niitä tukevien verkkosivujen avulla. Kukahan päivittäisi laitoksen ja aineemme verkkosivut ja linkittäisi ne Aaltoyliopiston uusiin opiskelijasivustoihin tänä vuonna?

\section{Opinto-ohjelmien arvioinnit ja raportointityö}

"Torstai 2.11. - Saan viestin Aalto-yliopiston opetuksen arvioinnin aikatauluista. Englanniksi tehtävä arviointi käsittää 115 ohjelmakohtaista kysymystä, joihin tulee vastata marras-tammikuun aikana. Arviointi koskee vanhoja kandi- ja maisteriohjelmia. Vaikka en olekaan tästä arvioinnista päävastuussa, kollegani on. Mitähän järkeä tässä on? Uusien ohjelmien suunnitteleminen on jo käynnistynyt, mutta niiden sijaan käytämme nyt ison osan 'joululomastamme' vanhojen ohjelmien arviointiin... Hei, hei tutkimus."

Opinto-ohjelmiin liittyvä arviointi- ja raportointityö on lisääntynyt viime vuosina, kun kauppakorkeakoulun johto on halunnut koulutukselle erilaisia laatuleimoja (esimerkiksi EQUIS, AMBA, AACSB) ${ }^{4}$. Lisäksi kauppakorkeakoulu on mukana erilaisissa verkostoissa, jotka edellyttävät meiltä myös tiettyjä asioita koulutuksen suhteen, kuten esimerkiksi vaihto-opiskelijoille suunnattuja opintokokonaisuuksia (esimerkkeinä PIM ja CEMS)5 . Kaikki nämä asiat kuorimittavat opinto-ohjelmien parissa työskenteleviä tahoja, sillä jonkun tulee tehdä näihinkin liittyvä suunnittelu-, arviointi- ja raportointityö. Aaltoympäristössä toimiminen on tuonut tähän vielä omia lisävivahteita ja omia arviointiprojekteja. Nämä ovat kuitenkin vain esimerkkejä ulkoapäin määritellystä arviointi- ja raportointityöstä. Parhaimmillaan opinto-ohjelmilla olisi omat vakiintuneet tavat kerätä palautetta ja arvioida opetusta, jotka tukisivat nimenomaan oman ohjelman toimijoita ja ohjelman kehittämistä.

\section{OPINTO-OHJELMIEN HALLINNAN JA KEHITTÄMISTYÖN HAASTEITA}

Olemme edellä nimenneet ja kuvanneet joukon työtehtäviä, joiden kautta osallistumme opinto-ohjel- mien hallintaan ja kehittämiseen. Työmaa on laaja, työtehtäviä on paljon ja ne liittyvät monin eri tavoin toisiinsa. Olemme myös kuvanneet opinto-ohjelmien parissa tehtävää työtä juuri sellaisena kuin se meidän arjessamme tällä hetkellä näyttäytyy: sekavana mahdollisuuksien ja pakkojen maailmana, jossa pitkäjänteinen yhteisen näkemyksen luominen on käynyt yhä vaikeammaksi. Henkilökuntamme on viime vuosina sekä lisääntynyt että vaihtunut kiihtyvällä vauhdilla. Voimistuva yksilöiden välinen kilpailu (työsuhteista, rahasta ja maineesta) ei myöskään ole helpottanut yhteistyön tekemistä opinto-ohjelmien parissa.

Opinto-ohjelmien hallintaa ja opetustyön pitkäjänteistä kehittämistä ei tue sekään, että ohjelmajohtajien ja assistenttien asemat ja vastuut ovat yksikössämme epäselviä. Itsekin työskentelemme määräaikaisissa työsuhteissa ja hoidamme opinto-ohjelmiin liittyviä työtehtäviä oman tutkimus- ja opetustyömme ohella. Tilannetta ei myöskään helpota se, että kaikkia tähän työhön osallistuvia yksittäisiä tutkijaopettajia arvioidaan ja palkitaan ensisijaisesti tutkimusjulkaisujen määrän mukaan.

Meidän on myös vaikea ymmärtää, miten kollegiaalisen kehittämis- ja yhteistyön edellytykset paranevat, kun yliopistoja ja niiden osia yhdistellään yhä suuremmiksi yksiköiksi. Uusiin asemiin nimitettyjen johtajien huoli hallinnollisten muutosten onnistumisesta ja yliopiston johdon tarve "osallistaa" tutkijaopettajia milloin mihinkin arviointi- tai kehittämishankkeeseen on helpompi havaita omassa arjessaan. Korkeakoulu- ja laitoskohtaisten opintoohjelmien uudistaminen on selkeä esimerkki tällaisesta muutospaineesta ${ }^{6}$. Tällaiset omaa arkista työtä ja yksikkömme ohjelmatyöskentelyä hiertävät haasteet lienevät tuttuja monille muillekin yliopistoissa työskenteleville tutkijaopettajille.

Tämän artikkelin käsikirjoitusluonnosta lukeneet kollegamme kaipasivat ohjelmallisuutta määrittäville työtehtäville myös jonkinlaista selkeämpää järjestystä tai tehtävien välistä hierarkiaa: "Eikö näistä työtehtävistä muodostu mitään selkeämpää kokonaisuutta tai käytännettä? Vai onko niin, että joskus aiemmin toimineet käytänteet ovat vanhentuneet eivätkä enää toimi monien muutosten keskellä?”

Omat vastauksemme näihin kysymyksiin ovat 
ristiriitaisia. Viime vuosien aikana käynnistettyjen muutosten määrää, mielekkyyttä ja niiden vaikutuksia opinto-ohjelmien parissa tehtävään työhön on vaikea tunnistaa ja hahmottaa. Oma epävarmuus arkisen puurtamisen keskellä ja kollegoidenkin huoli tulevasta uuvuttaa. Jatkuvien muutosten ja ohjelmien muutospyrkimysten rinnalla jo olemassa olevat opinto-ohjelmatkin pyörivät koko ajan. Niihin hakeudutaan, niissä opiskellaan ja opetetaan, olivat ne sitten minkä kokoisia tai nimisiä tahansa. Kokemuksemme on myös se, että vuosittainen opinto-oppaiden kokoamiseen ja toimittamiseen kiteytyvä opetuksen suunnittelutyö on aiemmin toiminut paremmin. Opinto-ohjelmien omaehtoinen hallinta ja kehittäminen on siis ainakin ollut mahdollista - ainakin omassa yksikössämme (ks. Räsänen, tulossa).

Kysymys kuuluu: miten opinto-ohjelmien toteuttamiseen, hallintaan ja kehittämiseen osallistuvien toimijoiden kesken voidaan löytää riittävä yhteisymmärrys siitä työstä, jota pitkäjänteinen ohjelmatyöskentely edellyttää? Miten tätä yhteisymmärrystä voidaan tavoitella nykyisessä toimintaympäristössämme? Haaste on kollektiivinen, monitahoinen ja hyvin ajankohtainen (vrt. Ylitalo et al. 2011).

\section{OHJELMATYÖSKENTELY KÄYTÄNNÖLLISENÄ TOIMINTANA}

Yksi tapa, jolla tähän haasteeseen voi tarttua, on tarkastella ohjelmatyöskentelyä käytännöllisenä toimintana. Toisin sanoen, pitkäjänteisen opinto-ohjelman kehittämisen edellyttämää yhteisymmärrystä voi ainakin tavoitella etsimällä vastauksia käytännöllisessä toiminnassa kohdattaviin peruskysymyksiin: Kuinka tämän työn teen? Mitä yritän näin saada aikaan ja saavuttaa? Miksi pyrin näihin tavoitteisiin juuri näillä keinoilla? Ja kuka olen, kun teen tätä juuri näin ja näillä motiiveilla tai oikeutuksilla? (Ks. Räsänen 2008; Räsänen 2009a)
Tämä tulkinta käytännöllisessä toiminnassa kohdattavista peruskysymyksistä perustuu MERI-tutkijaryhmämme piirissä kehiteltyyn lähestymistapaan $^{7}$, jonka avulla voi tutkia myös opinto-ohjelmien parissa tehtävää työtä. Tässä lähestymistavassa ei tehdä vahvoja ennakko-oletuksia toiminnan keinoista, tavoitteista, motiiveista tai tekijöistä - eikä näiden keskinäisestä yhteensopivuudesta. Olennaista ohjelmatyöskentelyn tarkastelussa käytännöllisenä toimintana onkin tutkia sitä, miten eri tavoin työtehtäviä hoidetaan ja mitä ohjelmaa luovat ja ylläpitävät toimijat yrittävät näin saada aikaan. Miksi tietynlaisia tavoitteita pidetään mielekkäinä tai mahdollisina ja millaiset toimijat tätä työtä oikein tekevät?

Lähestymistapa ei siis tarjoa sitä yhtä "oikeaa" ratkaisua siihen sekavaan mahdollisuuksien ja pakkojen maailmaan, jota tämän artikkelin alkupuolella kuvasimme. Kyse on pikemminkin väljästä ja moniulotteisesta lähestymistavasta, jonka avulla opinto-ohjelmien parissa työskentelevät toimijat voivat tutkia omaa toimintaansa, keskustella siitä keskenään ja ainakin yrittää ymmärtää miten samassa ohjelmassa työskentelevät opettajakollegat toimivat. Toisin sanoen, paikallisesti määrittyvien toiminnan taktiikoiden, poliittisten tavoitteiden, moraalisten motiivien ja oikeutuksien hahmottaminen voi helpottaa tutkijaopettajia reflektoimaan omaa toimintaansa ja hakemaan näin yhteisymmärrystä siitä, millaisessa ohjelmassa ja keiden kanssa he työtään tekevät.

Ohjelmatyöskentelyn taktiikka, politiikka ja moraali

Myös kauppatieteellisessä koulutuksessa on hyvä kysyä mitä koulutuksella yritetään saada aikaan ja saavuttaa. Ohjelmien parissa työskentelevillä kun ei aina ole edes tietoa siitä, miten erilaisia kauppatieteellisen koulutuksen mallit voivat olla (Korpiaho et al. 2007). Opinto-ohjelmien tavoitteet voivat liittyä esimerkiksi siihen, koulutetaanko tulevia liike-elä- 
OPINTO- män johtajia, akatee-

OHJELMIEN

TAVOITTEITA

MIETITT ÄESS Ë EI

PITÄISI UNOHTAA

SIT $\ddot{A}$, ETT $\ddot{A}$

KASVATUKSESSA

TAI KOU-

LUTUKSESSA

JOUDUTAAN AINA

TEKEM ̈̈̈̈N MYÖS

POLIITTISIA

VALINTOJA.

misesti koulutettuja tiettyjen alojen spesialisteja, refleksiivisiä ja autonomisia asiantuntijoita, vastuullisia kansalaisia vai poliittisesti valveutuneita aktiivisia toimijoita. Opintoohjelmien tavoitteita mietittäessä ei pitäisi unohtaa sitä, että kasvatuksessa tai koulutuksessa joudutaan aina tekemään myös poliittisia valintoja.

Jotta opinto-ohjelma voisi toteutua sekä opiskelijoille että opettajille mielekkäänä kokonaisuutena, tarvitaan yhteistä sopimista ja neuvottelua siitä, miten opinto-ohjelma ymmärretään, millaisia tavoitteita sille asetetaan ja miten se aiotaan toteuttaa. Yhteisymmärrystä voidaan siis tavoitella työstämällä sekä koulutusohjelman tavoitteita että keinoja. Tällainen työskentely täytyy myös järjestää siten, että keskeisiin kysymyksiin voisi yhdessä etsiä toimivia ratkaisuja.

Parhaimmillaan kaikki opinto-ohjelman kurssit ja nilllä käytettäørätt työskentelytavat tukevat ohjelnmalle asetettuja tavoitteita ja keinoja johdonmukaisella tavalla, joka on myös kurssien vastuuopettajien kanssa yhdessä mietitty ja sovittu. Kursseilla käytettävät työmuodot voivat vaihdella perinteisestä luento-opetuksesta opiskelijoiden osallistuvaan, toimintatutkimukselliseen työskentelyyn (ks. esimerkiksi Korpiaho et al. 2007). Jos saman opinto-ohjelman sisällä on kovin erilaisia työskentelymuotoja, opiskelijoilta menee valtavasti aikaa ja energiaa sen oivaltamiseen, mitä heiltä kullakin kurssilla odotetaan. Samoin jotkut työskentelymuodot ovat niin haastavia, että niitä olisi hyvä harjoitella johdonmukaisesti läpi koko ohjelman. Esimerkiksi oman yksikkömme maisteriohjelmassa mainittu reflektiivinen ja tutkiva työote on juuri tällainen työskentelytapa.
Taktiikan ja politiikan lisäksi opinto-ohjelmissa tulisi ajatella myös sen moraalista perustaa. Toisin sanoen, miten perustelemme sen, että pyrimme juuri tiettyihin tavoitteisiin juuri tietyin keinoin? Onko taustalla viime kädessä ajatus siitä, että koulutuksen tulisi tarjota yksilöille menestymismahdollisuuksia (mainetta, statusta ja varallisuutta) vai onko koulutuksen taustalla käsitys tiettyjen professioiden tukemisesta (ammattitaito ja moraalinen vastuullisuus), tietynlaisesta yhteiskunnan taloudellisesta hyvästä (tuottava, osaava ja kilpailukykyinen työvoima) vai pyrkimyksestä yhteiskunnan kehittämiseen (demokratia, tasa-arvo, työelämän kohtuullisuus)?

Moraalin äärellä on siis kyse siitä, millaisia hyviä (asioita) opinto-ohjelmassa tavoitellaan ja millaisia 'hyveitä' niiden toteuttaminen edellyttää (ks. MacIntyre 1981$)^{8}$. Omassa yksikössämme hyvin toimivaa opinto-ohjelmaa on tavoiteltu arvostamalla tutkijaopettajien omaa asiantuntemusta ja kunnioittamalla sekä opiskelijoiden että opettajien akateemista vapautta. Tutkijaopettajille on vuosien varrella annettu paljon tilaa omaehtoiseen opetustyön ja kurssien kehittämiseen, vaikka välillä kehittämistyötä joudutaan tekemään myös opetusministeriön ja yliopiston johdon linjausten mukaisesti. Näkemystä opinto-ohjelman tavoitteista ja keinoista on myös työstetty yhdessä ohjelmassa opettavien tutkijoiden kesken (ks. Räsänen, tulossa). Opiskelijoita on puolestaan neuvottu tekemään itse rohkeita valintoja tarjolla olevista opintojaksoista ja erikoistumisvaihtoehdoista oman kiinnostuksensa pohjalta.

Parhaimmillaan tällainen pyrkimys on toiminut ohjelmallisuuden rakentavana, kollegiaalisena perustana (vrt. Korhonen 2007). Vaikka kollegiaalisuus onkin monen tutkijaopettajan mielestä ollut yksi aineyksikkömme ohjelmatyöskentelyn hyvistä asioista (Mäntylä \& Päiviö 2005), yhteisymmärryksen löytäminen opinto-ohjelman moraalisesta perustasta ei kuitenkaan ole ollut helppoa. Hyvistä asioista on vaikea puhua yleisesti ja omankin (opetus)työn mielekkyydelle voi olla vaikea löytää oikeita sanoja. Hyvät asiat voivat myös olla hyvin henkilökohtaisia. Herkistyminen niiden tunnistamiseen vie aikaa ja edellyttää sekä jonkinlaista luottamusta työn jatkuvuuteen että rohkeutta keskustella itselle tärkeistä asioista samassa 
ohjelmassa toimivien kollegojen kanssa. Kokemuksemme on myös se, että monien muutosten, katkonaisten, epäselvien ja epävarmojen työsuhteiden keskellä tarve tällaiselle moraaliselle keskustelulle on juuri nyt erityisen suuri.

\section{OHJELMATYÖSKENTELYN SUBJEKTIT}

Kysymys ohjelmatyöskentelyn subjekteista on alue, jolla omat kokemuksemme viime vuosilta ovat erityisen ristiriitaisia. Useiden kurssien opettajina, ohjelmajohtajana ja opinto-oppaan toimitustyöstä vastaavana assistenttina olemme seuranneet ohjelmatyöskentelyä hyvin läheltä omassa aineyksikössämme, laitoksellamme ja korkeakoulussamme laajemminkin. Oma opetuskokemus, asemiimme liittyvät työtehtävät ja omassa yksikössä tekemämme osallistuva tutkimus ovat avanneet laajan näkymän tähän sekavaan mahdollisuuksien ja pakkojen maailmaan, jossa ohjelmatyöskentelyn subjektit etsivät sekä itseään että toisiaan. Tähän ammatillisten identiteettien etsimiseen liittyvät haasteet ovat sekä henkilökohtaisia että kollektiivisia.

Yksittäisinä opettajina voimme tarkastella omaa toimintaamme opetuksen parissa ja etsiä vastauksia edellä mainittuihin miten, mitä ja miksi kysymyksiin. Ratkomalla näitä käytännöllisen toiminnan peruskysymyksiä voimme ymmärtää paremmin, millaisia opettajia tai kouluttajia ”omilla kursseillamme" ehkä olemme ja millaisiksi mahdollisesti haluamme tulla. Etsimällä ratkaisuja omaan toimintaani liittyviin ristiriitoihin voin myös itse pyrkiä kehittämään opetustyötä minulle mielekkääseen suuntaan. Voin tarvittaessa muuttaa kursseillani käytettäviä työskentelytapoja, voin tarkistaa kurssille asetettuja tavoitteita ja kertoa opiskelijoille, miksi tällä kurssilla pyrimme juuri näihin tavoitteisiin juuri näillä työskentelytavoilla. Voin myös perustella kursseillani tehtyjä ratkaisuja ohjelman muilla kursseilla asetetuilla odotuksilla ja vaatimuksilla, jos tiedän millaisiin ratkaisuihin kollegani ovat niillä päätyneet.

Ohjelmajohtajan tai assistentin asemasta katsoen kysymys ohjelmatyöskentelyn subjekteista muuttuu monin verroin haasteellisemmaksi. Tällöin emme enää voi keskittyä vain omaan opetustyöhömme ”omilla kursseillamme" ja oman ammatillisen identi- teetin jalostamiseen. Joudumme sen sijaan etsimään ja usein myös esittämään vastauksia (esimerkiksi ohjelman opiskelijoille ja ulkopuolisille arvioijille) koko ohjelman tavoitteista ja työskentelytavoista. Toisin sanoen, joudumme tällöin etsimään vastauksia käytännöllisen toiminnan peruskysymysten kollektiivisiin me-muotoihin: miten opetustyötä tehdään johtamisen ohjelmissa, mitä me - noin 30--40 kursseilla toimivaa tutkija-opettajaa - yritämme yhdessä saada aikaan (yli 200 opiskelijan kanssa) ja miksi juuri näin? Kuinka hyvin tutkijaopettajat perustelevat omia ja tunnistavat toisten tekemiä ratkaisuja ohjelman eri kursseilla? Kuinka johdonmukaisia ratkaisut ovat - tai voivat olla - toiminnan taktiikan, politiikan ja moraalisten motiivien osalta? Ja kuinka paljon me ohjelmajohtajana ja assistenttina lopulta tiedämme näistä ratkaisuista? Mistä me oikeastaan puhumme, jos puhumme ohjelman opettajista "me"-muodossa?

Vastausten löytäminen näihin kysymyksiin on erityisen haasteellista tilanteessa, jossa valtaosa ohjelman vastuuopettajista on määräaikaisia tai tilapäisesti oman tutkimustyönsä ohella opetukseen osallistuvia toimijoita. Suuri osa heistä ei voi olla varma siitä, ovatko he mukana opetustyössä myös seuraavana lukuvuonna. Monille heistä opinto-ohjelmaa tärkeämpää onkin hoitaa vain vuosittain sovitut opetustehtävät parhaaksi katsomallaan tavalla ja keskittää parhaat voimat omaan tutkimustyöhönsä. Aika ajoin järjestettävistä yhteisistä opetuksen suunnittelu- ja kehittämistilaisuuksista huolimatta tämän ”mekollektiivin" toimijat eivät koskaan tapaa toisiaan saman pöydän ääressä. Ei siis ole ihme, että valtaosa ohjelmatyöskentelyyn osallistuvista "subjekteista" ei tunne opinto-ohjelman tutkintorakennetta sen paremmin kuin ohjelman toisten kurssien sisältöjä, tavoitteita tai työskentelymenetelmiäkään.

Meidän näkökulmasta katsoen ensisijainen haaste ei siis ole vain yksittäisten kurssien ja niillä käytettyjen opetusmenetelmien kehittäminen tai yksittäisten opettajien pedagoginen kouluttaminen. Yksittäisten kurssien tai opettajien arviointi, "huippuopettajien" palkitseminen tai yleiset juhlapuheet opetuksen arvostuksen kohottamisesta eivät myöskään ole helpottaneet omaa työtämme viime vuosina. Mikäli artikkelimme alkupuolella esitettyihin ohjelmatyös- 
kentelyn työtehtäviin halutaan löytää toimivia ratkaisuja, niitä on käsiteltävä nimenomaan kollektiivisina haasteina. Jaettu käsitys tai näkemys siitä, mitä 'ohjelmallisuus' tarkoittaa ja millaista (yhteis)työtä se "meiltä" edellyttää koko ohjelman tasolla, helpottaisi omaa työtämme merkittävästi.

\section{LOPUKSI}

Opiskelua ja akateemista työtä koskeva tutkimus innostaa meitä ja toivomme, että monet yliopistoissa vireillä olevat ja tulevat kehittämisponnistelut perustuisivat vahvemmin myös alan tutkimukseen. Opinto-ohjelmien uudistamisen kannalta kiinnostavia aiheita olisivat esimerkiksi juuri tämän työn tekijöitä koskevat tutkimukset: keitä he ovat, millaista heidän työnsä on ja millaisin edellytyksin he sitä tekevät? Miten opinto-ohjelmien parissa työskentelevät toimijat kamppailevat vaikkapa oman tutkimuksen, kollegiaalisen vastuuntunnon, koulutusohjelmiin liittyvien ideaalien, yliopiston urajärjestelmien sekä työn ja perhe-elämän ristiaallokossa?

Ohjelmatyöskentelyn tarkasteleminen käytännöllisenä toimintana avaa mielestämme puhuttelevia näköaloja siihen, miten eri tavoin ohjelmatyöskentelyyn liittyviä työtehtäviä voidaan hoitaa ja miten voisimme ainakin yrittää kohdata toisemme tässä sekavassa mahdollisuuksien ja pakkojen maailmassa. Vaikka tässä paperissa esittelemämme lähestymistapa ei tarjoakaan valmiita ratkaisuja näihin ohjelmatyöskentelyn haasteisiin, se kuitenkin mahdollistaa keskustelun tärkeistä asioista. Jos esimerkiksi sa- massa opinto-ohjelmissa toimiville tutkijaopettajille järjestetään riittävästi aikaa ja itse kullekin sopivia mahdollisuuksia osallistua tällaiseen keskusteluun, olemme ainakin askelen lähempänä omaehtoista opinto-ohjelmien hallintaa ja kehittämistä. Tämä ei vielä takaa sitä, että löydämme yhteisymmärryksen siitä, mitä ohjelmallisuudella oikein tarkoitetaan tai miten siihen liittyviä työtehtäviä voidaan hoitaa hyvin. Omaehtoinen ohjelmatyöskentelyn taktiikkaa, politiikkaa, moraalia ja subjekteja koskeva keskustelu tuntuu kuitenkin mielekkäämmältä yritykseltä kuin antautuminen jonkun muun määrittelemien, ulkoisten 'hyvien' vietäväksi.

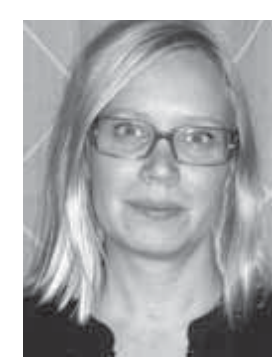

Kirsi Korpiaho

KTM, tutkija

Aalto-yliopisto/Helsingin

kauppakorkeakoulu

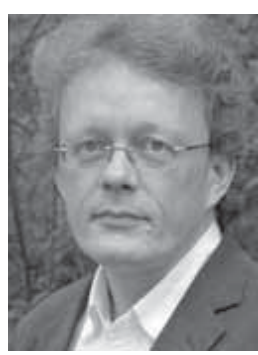

Hans Mäntylä

KTT, yliassistentti, ohjelmajohtaja Aalto-yliopisto/ Helsingin

kauppakorkeakoulu

\section{LÄHTEET}

Barnett, R. \& Coate, K. (2005). Engaging the curriculum in higher education. Maidenhead: McGraw-Hill/Open University Press.

Haggis, T. (2009). What have we been thinking of? A critical overview of 40 years of student learning research in higher education, Studies in Higher Education, 34(4), 377-390.

Korhonen, V. (2007). Individualistista vai kollegiaalista työkulttuuria yliopistoyhteisössä. Teoksessa V. Korhonen (toim.) Muuttuvat oppimisympäristöt yliopistossa? Tampere: Tampere University Press.

Korpiaho, K., Päiviö, H. \& Räsänen, K. (2007). Anglo-
American forms of management education: A practice-theoretical perspective. Scandinavian Journal of Management, 23, 36-65.

Maclntyre, A. (1981). After virtue: A study in moral theory. Notre Dame: University of Notre Dame Press.

Mäntylä, H. (2007). On "good" academic work practicing respect at close range. Acta Universitatis Oeconomicae Helsingiensis, A-306. Helsinki: HSE publications. 
Mäntylä, H. \& Päiviö, H. (2005) Toivon ja epätoivon äärellä akateemisessa työssä. Teoksessa: H. Aittola \& O.-H. Ylijoki (toim.) Tulosjohdettua autonomiaa: Akateemisen työn muuttuvat käytännöt. Helsinki: Gaudeamus, 41-66.

Postareff, L. \& Lindblom-Ylänne, S. (2008) Variation in teachers' descriptions of teaching: broadening the understanding of teaching in higher education. Learning and Instruction, 18(2), 109-120.

Räsänen, K. (tulossa) "That's dangerous". Autonomous development work as a source of renewal in academia. Käsikirjoitus teokseen: Bjorn Stensaker, Jussi Välimaa \& Cláudia S. Sarrico (toim.) Managing Reform in Universities. Palgrave.

Räsänen, K. (2008) Mikä yliopistotyöntekijää liikuttaa? Tiedepolitiikka 2/08, 17-27.

Räsänen, K. (2009a) Understanding academic work as practical activity -- and preparing (business-school) academics for praxis? International Journal for Academic Development, 14(3), 185-195.
Räsänen, K. (2009b). “Opinto-ohjelma: mikä se on, mihin sitä käytetään, ja miksi se on tärkeä myös kauppakorkeakoulussa?", Julkaisematon muistio, Helsingin kauppakorkeakoulu.

Räsänen, K. \& Korpiaho, K. (2007). Experiential learning without work experience: reflecting on studying as 'practical activity'. In: M. Reynolds \& R. Vince (Eds.) The handbook of experiential learning and management education. Oxford: Oxford University Press, 87-104.

Ylitalo, J., Syrjäkari, M. \& Hyppönen, O. (2011). Opetuksen johtaminen oppimiskeskeisen yliopistokulttuurin edistäjänä - ajatuksia Aallosta. Peda-Forum 1/11, 31-34.

Yhdenmukaisen eurooppalaisen korkeakoulutusalueen rakentaminen.

\section{VIITTEET}

1 Nämä ovat uusia Aalto-yliopistoon perustettuja monialaisia, usean yksikön yhteistyönä suunniteltuja kandi- tai maisteriohjelmia, joihin opiskelijat valitaan oman erillishaun kautta.

2 Aalto-yliopiston kauppakorkeakoululla, tekniikan korkeakouluilla ja taideteollisella korkeakoululla on kaikilla erilaisia koulutusohjelmia vaihtelevine tutkinto-rakenteineen ja suoritussäännöksineen. Lisäksi Aalto-yliopistossa on ns. poikkitieteellisiä Aalto-ohjelmia, joihin hakeudutaan erikseen. Vuoden 2011 aikana kaikki vanhat ohjelmat arvioidaan Teaching Evaluation Exercise -arviointiprojektissa. Jo aiemmin kauppakorkeakoulun opetusta on arvioitu toistuvasti.

3 Nämä ovat uusia Aalto-yliopistoon perustettuja monialaisia, usean yksikön yhteistyönä suunniteltuja kandi- tai maisteriohjelmia, joihin opiskelijat valitaan oman erillishaun kautta.

4 The European Quality Improvement System (EQUIS) -laatuleima; Association of MBAs (AMBA) myöntämä laatuleima; The Association to Advance Collegiate Schools of Business (AACSB) akkreditointi.

5 Partnership in International Management (PIM); The Global Alliance in Management Education (CEMS)
6 Itse olemme viimeksi kuluneen vuoden aikana olleet mukana uudistamassa nykyistä Johtamisen maisteriohjelmaa ja koulumme kandiohjelmaa sekä suunnittelemassa uuden laitoksemme uutta maisteriohjelmaa ja Aalto-yliopistoon perustettavaa uutta poikkitieteellistä "Aalto+ -kandiohjelmaa". Tämän lisäksi yksikkömme henkilökunta on ollut mukana käynnistämässä kahta uutta maisteriohjelmaa ("Strategia-" ja "Corporate Social Responsibility -ohjelmat").

7 Kirsi Korpiahon, Keijo Räsäsen ja Hanna Päiviön tutkimus (2007) tarjoaa esimerkin siitä, miten he tämän lähestymistavan avulla tunnistivat ja vertailivat erilaisia anglo-amerikkalaisia johtamiskoulutuksen malleja.

8 Maclntyre (1981) erottelee nämä hyvät asiat edelleen 'sisäisiin' ja 'ulkoisiin hyviin'. Hänen mukaansa käytännöllisen toiminnan vakiintuneessa muodossa pyritään toteuttamaan sille erityisiä sisäisiä hyviä asioita. Nämä ovat eri asia kuin toimintaa tukemaan perustetun instituution tavoittelemat ulkoiset hyvät, kuten raha, status ja maine. 